\title{
Editorial: Welcome to our New Reviews Editor
}

\author{
Rina Agarwala, Jenny Chan, Alexander Gallas, Ben Scully
}

Since the founding of the Global Labour Journal, Katherine Joynt has tirelessly served as the Journal's Reviews Editor, providing us with high-quality, critical book reviews of the latest works in global labour studies. Katherine has recently decided to move on to other endeavours and will no longer be a member of the Journal's editorial team. We would like to express our deep appreciation for her work over the years.

At the same time, we are delighted to introduce our new Reviews Editor, Jörg Nowak. Jörg has been involved in various labour struggles in Germany, both as an academic and as a campaigner. He has also been a regular contributor to the GLJ. He co-authored "Mass Strikes against Austerity in Western Europe", authored "Union Campaigns in Germany directed against Inequality", and reviewed Felix Hauf's book Beyond Decent Work: The Cultural Political Economy of Labour Strategies in Indonesia.

Jörg has a PhD in Politics from the University of Kassel. He is the author of Gender Politics and Class Domination: An Integration of Marxist and Feminist Theories of the State (2009, Westfälisches Dampfboot, in German). Currently, he is conducting research on the politics of labour of Taiwanese electronics companies operating in India and Brazil, Chinese-owned energy companies in Brazil, and labour geography. Jörg is presently a Visiting Assistant Professor at the Department of Asian and International Studies, City University of Hong Kong. From September 2017, he will hold a Marie Curie Fellowship at the School of Politics and International Relations, University of Nottingham.

We invite our readers to inform us about new books on global labour that they believe are worth reviewing in our Journal. We also welcome suggestions for reviewers. Book review submission guidelines can be found on the GLJ's website. As with our articles, we are especially interested in books on topics such as the relationship between labour movements and other social movements, the role of labour in contesting austerity, authoritarianism and the rise of the far right, the role of the public sector in union revitalisation, new strategies of union organisation and mobilisation, strategies against economic inequality, and processes of union organisation that target transnational production networks. Moreover, in order to introduce our readers to debates outside the Anglophone world, we would like to see English-language reviews of books in other languages.

Furthermore, we would like to announce that the GLJ will organise another "authors meet critics" session at the World Congress of the International Sociological Association in Toronto in July 2018. The session will focus on several recently published, outstanding books from the field of global labour studies. We invite submissions of books published from 2015 onwards; suitable languages are English, French or Spanish to reflect the host region's languages. Nominations by the author(s) or others can be sent to the ISA online platform until 31 January 2018. Reviews of the featured books will be published in the September 2018 issue of the Global Labour Journal.

Global Labour Journal, 2017, 8(2), Page 99 